\title{
USE OF PICTURE AND PICTURE METHOD IN INCREASING ABILITY OF SUNWARE STUDENTS
}

\author{
Marta Indri Hapsari \\ Gamaliel Christian Primary School, Bandung City, West Java, Indonesia \\ martaindri10@gmail.com
}

\begin{abstract}
The main issues of this research is how to improve the ability of elementary school students (ES) in recognizing the sun through picture and picture method. The objectives of the research are as follows: (1). Improving the ability of elementary students in recognizing the sun through picture and picture method; (2). Provide learning through picture and picture method that improves students' ability. The methods / approaches used in achieving the following objectives: (a). Collect students and elementary teachers involved in research; $(B)$. Provide an overview of the research activities to be undertaken; (C). Reflecting, discussing about learning with picture and picture method; $(D)$. Collaborate with elementary teachers in the determination of experimental class and control class; (E). Implementation of learning method picture and picture; $(F)$. Evaluation of learning with picture and picture method. The results showed that there is an increase in the ability of elementary students in recognizing the sun through the study of picture and picture method by 19\%; (2). Elementary students are enthusiastic about learning the picture and picture method given by the teacher.
\end{abstract}

Keywords: Method, Learning, Picture and picture.

\section{INTRODUCTION}

This research was conducted to find out the relationship between Picture and Picture (PnP) method with the students' ability to recognize the sun for the fifth grade students in elementary school especially on the study of Natural Sciences considering that nowadays a lot of learning is done in elementary school only by using lecture or demonstration method Only.

Given that the curriculum of learning in schools now turns into a National Curriculum that refers to student-centered learning (Student Center), Teacher Center is not the only teacher and teacher as a classroom learning facilitator. In the national curriculum, students must further explore the learning or science based on the theme and the learning process should be done in real way so that the students gain direct experience in the learning process. As in the learning activities so many learning methods that we can do to make the students more interested in learning activities in elementary and exploring at home. Here researchers will use one of the methods of learning is PnP method to further explore the interest and learning activities of students on science learning.

Based on Law No.20 Year 2003 article 37 on Sisdiknas (2003), the curriculum of KTSP in science subjects in 2006 aims to make students have the following capabilities:

1. Know the concepts related to society and the environment. 
2. Have basic skills for logical and critical thinking, curiosity, inquiry, problem solving, and skills in social life.

3. Have a commitment and awareness of social values and humanity.

4. Have the ability to communicate, work together and compete in a pluralistic society, local, national, and global. (Gunawan, 2011).

Referring to Law No.20 of 2003 on National Education System, researchers hope that science subjects in elementary school can be understood by students and can be actualized in daily life by students with PnP method in school. The implementation of the PnP method is expected to enable students to use inductive reasoning to develop more enjoyable learning.

Through the application of PnP method, it is expected that 5th graders can improve their ability to know the sun. Based on the problems that developed above, this study focuses on the study "Application of PnP Method in Improving Student's ability to know the Sun".

\section{A. The Things Underlying Research}

The things underlying this study are based on general research data that has been previously disclosed and field observation records in general where the process of learning in elementary school is still far from expectations that should be able to better enable students' abilities. In learning Social science in the class for example, often less meaningful learning process for students. Students just sit sweet and silent, listen to the teacher's explanation, many teachers stand in front of the class explain the subject matter, and teachers tend to be more active lectures themselves. There is also an indication that teacher pedagogy practices are less appropriate to the topic and do not have an appropriate focus so that experience, understanding does not develop optimally.

The 21st Century National Education Paradigm states that the strategy of achieving education in the future one of them is by applying different learning methods in elementary school. This method holds to the principle that each individual is unique and has their own talents, so the learning method must take into account the diversity of "learning style" of each individual. Through different learning activities through the use of this PnP method, students are expected to further develop their abilities.

Learning models that emphasize these characteristics and diversity need to be developed. Examples of learning models in question include PBL (Problem Based Learning) and $\mathrm{PnP}$ methods. In addition, emphasis should be placed on cooperative learning models among individuals to improve their interpersonal and social competence, such as: 
Cooperative Learning and Collaborative Learning through learning activities based on the PnP method.

The things that happened that have been expressed before can be understood as the truth that really happened in elementary school. Thus there is need for assistance and research that can provide examples of various learning with $\mathrm{PnP}$ method so that students and teachers are more excited and open to study harder. Through this research, we hope to find meaningful findings on the extent to which the PnP method of improving students' ability to recognize the sun. The specific problems we may face are the reluctance of students and elementary teachers to our presence, but through collaborative discussions, we are confident that this will be resolved and this research will provide deep meaning to all of us.

The PnP method is a learning model based on the constructivism approach of Piaget and Vygotsky. Constructivism understands the essence of learning as a human activity of building or creating knowledge by trying to give meaning to knowledge according to experience (Nurohman: 2008).

The PnP Method is a model designed to engage students in digging information and inquiring, conducting and finding, collecting data and analyzing and making their own inferences. In this model students are given the freedom in constructing thoughts and findings during the activity so that students do themselves without the burden, fun and high motivation so that learning will be more meaningful. The PnP method of learning emphasizes the development of reasoning, model building, its association with real-world applications or everyday life and can make students have hands-on experience, so as to overcome learning problems such as difficulty in recalling the subject matter (Starrett and Morcos, 2001); (Raviv Daniel, 2004); And (Atles and Ali, 2011).

Characteristics of the PnP method are: independent, mutually supportive, happy, passionate learning, integrated learning, using multiple sources, active, fun, not boring, sharing with friends, critical and creative students. The PnP method can also provide an indepth appreciation of what is learned, so that what is obtained by students is not easily forgotten because students gain that knowledge directly through their own experience. By learning the PnP method, students can appreciate the concepts taught by the teacher, the students can prove facts and concepts, and also encourage the students 'curiosity more deeply so that it tends to arouse students' desire to conduct research to gain observation and experience in the scientific process. Through the PnP method, students can also benefit from: increase interest, motivation, strengthen memories, can overcome problems of learning 
difficulties, avoid misunderstandings, get feedback from students and connect the concrete and abstract. (Weinberg, Ithaca and Thomas, 2009) and (Ivers and Whitney, 2009).

In the implementation of learning with PnP method is to be really effective need to pay attention to student learning activities. The PnP method allows learners to be independent, courageous to ask questions, explore curiosity and become creative learners. A teacher can and should be able to give the student experience, at least ten minutes to the student where the student can feel, hear, see, and act on the subject to be taught for the rest of the time. This can create a fun atmosphere, reduce student boredom and learn more effectively.

\section{B. Problem Formulation}

Based on the background that has been disclosed before, this research is directed to answer the problem as follows: "How to Use PnP Method in Increasing Ability of Elementary School Students in Knowing the Sun?". Our problems are detailed through the following research questions:

1. Can the PnP method improve students' ability to recognize the sun?

2. How much is the improvement of the ability of elementary school students to recognize the sun doing the learning through PnP method?

\section{Limitations of Research}

Based on the formulation of the problems that have been disclosed, it is necessary to limit the research to make this research more focused. The research limits are given as follows:

1. This research is limited to elementary school science lesson.

2. The subject of the research is the 5th grade elementary school students.

3. Learning is done through the use of learning with PnP method.

4. The learning outcomes measured are the students' ability to recognize the sun through the test of learning outcomes in the form of a description.

\section{Research purposes}

The purpose of this study as follows:

1. To obtain an effective and efficient learning method that can improve the ability of primary school students in knowing the sun. 
2. To obtain the Student Worksheet tool for learning PnP methods developed to guide students in order to develop their ability optimally.

3. To obtain an appropriate evaluation tool to be able to test the achievement of students' ability to recognize the sun through learning PnP method given.

4. To obtain information on the feasibility of the PnP method given in its implementation.

5. To facilitate teachers in delivering learning materials should be given by PnP method.

6. To direct elementary school students in gaining more knowledge and experience through PnP method learning.

\section{E. Output Target}

The expected output target for this research activity is as follows:

1. The availability of guidebook manual for mechanism of how to develop learning activity of PnP method in elementary school.

2. The results of research that can be used as material as data and facts when this activity is done, can be a material of further study for the material of final project completion (thesis) / research and can be published nationally through the available educational journals.

3. The existence of a follow-up research program for the next program development year based on the evaluation of the program undertaken.

4. As a study material, as for the follow-up research program that can be done as follows: the increase of students and teachers who do learning with PnP method.

5. Increased understanding of learning at elementary level for students, as well as teachers.

One model that is currently popular in learning is the model of learning Picture and Picture $(\mathrm{PnP})$ is one form of cooperative learning model. Cooperative learning model is a model of learning that prioritizes the existence of groups. Cooperative learning is a learning that consciously and systematically develops interaction with each other, silih asih, and silih asuh. PnP learning model is a learning method that uses images and paired / sorted into a logical sequence.

This learning has an active, innovative, creative, and fun character. Any model used always emphasizes the active students in every learning. Innovative learning should provide something new, different and always attract students. And creatively, each learner must generate an interest in the student to produce something or be able to solve a problem by using methods, techniques or methods mastered by the students themselves derived from the learning process. 
This learning model relies on images as a medium in the learning process. These images become the main factor in the learning process so that before the learning process the teacher has prepared the image that will be displayed either in the form of cards or in the form of treasures in large size. Or if at school already using ICT in using power point or other software. According to Johnson \& Johnson, the basic principle in the cooperative learning model PnP as follows:

1. Each member of the group (student) is responsible for everything done in his group.

2. Each group member (student) must know that all group members have the same goals.

3. Each member of the group (student) must share the same duties and responsibilities among the members of his group.

4. Each group member (student) will be subject to evaluation.

5. Each group member (student) shares leadership and requires skills to learn together during the learning process.

6. Each member of the group (students) will be required to individually account for the materials handled in the cooperative group.

As the name implies, this type uses the image media in the learning process that is by installing / sorting the pictures into a logical sequence. Through this way students are expected to think logically so that learning becomes meaningful.The steps in the PnP learning model are as follows:

1. The teacher conveys the competence to be achieved.

In this step the teacher is expected to convey what is the Basic Competence of the subject in question. Thus the students can measure to what extent should be mastered. Besides, the teacher must also present indicators of achievement of basic competence, so that until the limits of predetermined value can be achieved by the learners.

2. Present the material as an introduction.

Presentation of the material as an introduction to something very important, from here the teacher gives the momentum of the beginning of learning. Success in the learning process can start here. Because teachers can provide motivation that attracts the attention of students who have not been ready. With good motivation and techniques in the delivery of materials will attract students to learn more about the material being studied.

3. Teacher shows / shows pictures of activities related to the material.

In the process of presenting the material, the teacher taught the students to be actively involved in the learning process by observing each picture shown by the teacher or by his friend. With images we will save our energy and students will more easily 
understand the material being taught. In subsequent developments as teachers can modify images or replace images with video or demonstration of specific activities.

4. Teachers appoint / invite students to alternately install / sort pictures into a logical sequence.

In this step the teacher should be able to innovate, because direct appointment is sometimes less effective and students feel punished. One way is by lottery, so students feel they have to perform the tasks that must be given. Existing pictures are required by students to be ordered, created, or modified.

5. Teacher asks the reason / rationale for the sequence of images.

After that invite students to find the formula, height, storyline, or basic competence demands with indicators to be achieved. Invite as many as possible the role of students and other friends to help so that the process of discussion in learning more interesting.

6. From the reason / sequence of images the teacher embarks embed the concept / material in accordance with the competence to be achieved.

In the process of discussion and reading of this picture the teacher should give emphasis to this accomplished by asking another student to repeat, write or other forms with the student's goal of knowing that it is important in achieving the $\mathrm{KD}$ and the indicator that has been set. Make sure that the student has mastered the predefined indicator.

7. Conclusion / summary.

At the end of the lesson, the teacher and the students come to the conclusion as a reinforcement of the subject matter. The advantages of PnP learning model as follows:

1. The teacher is more aware of the ability of each student.

2. Train logical and systematic thinking.

3. Help students learn to think based on the point of view of a subject discussed by giving students freedom in the practice of thinking.

4. Develop motivation to learn better.

5. Students are involved in class planning and management.

Lack of PnP learning model as follows:

1. It takes a lot of time.

2. Many students are passive.

3. The teacher is worried that there will be chaos in the classroom. 
4. Many students are not happy when asked to cooperate with others.

5. Required support facilities, tools and costs are quite adequate.

\section{METHODS}

In learning a lot of media that we can actualize in learning so that students can receive the subject matter well and fun. One of them is the image media. In order for learning to use the media around the image can run smoothly it is necessary to have appropriate learning methods as a bridge so that students can receive the subject matter well and fun. One such method is the PnP method, where students can find their own core of the learning process in school and the teacher only provides reinforcement and concludes in the process of learning activities undertaken. The research will be carried out in several stages:

1. Planning.

2. Implementation.

3. Observation.

4. Reflection

The subjects of this study are five odd semester students totaling as many as 35 people consisting of students 18 men and 17 female students who are held at the Gamaliel Christian School in Bandung. The fifth grade was chosen as the subject of the study because the students needed immediate action to improve the students' activity and learning outcomes by applying PnP learning approach to the image media.

The study was conducted in two cycles so that there will be significant results. In each cycle the study consists of two meetings, one meeting for the implementation of learning and one meeting for the test of learning outcomes. The method used in data collection in this study is a test method that is carried out at the end of the cycle by using the test of learning outcomes to know the improvement of science learning outcomes. The test used is a written test. In this study the instrument used is the test of learning outcomes in the form of multiple choice tests.

For the purposes of collecting data related to the observer's task, the researcher and the partner researcher determine the necessary data collection techniques:

1. Observation Technique

Observations used are direct observation so as to know the actual state of the class and observe the activities of teachers and students during the learning process takes place.

2. Techniques 
The test is done to find out the students' understanding on the subjects of solar matter science.

3. Data Analysis Techniques

Data processing is an attempt by researchers to accurately summarize data that has been collected in a form that can be trusted and true. Data that have been collected by both researchers and partner researchers will be processed and analyzed.

\section{RESULTS AND DISCUSSION}

This research activity has been carried out in Gamaliel Bandung Christian Primary School and produced some findings that fit the title of "The Use of PnP Methods to Improve the Ability of Elementary School Students in Knowing the Sun". As described in the previous chapter, this study aims to improve the ability of Primary School students through PnP learning. Results and outcomes achieved in this study as follows. Research findings obtained in the form of findings of research results of students' abilities and data interviews. The findings are further analyzed and interpreted.

\section{A. Data on Student Learning Results}

The data obtained to determine student learning outcomes in the form of preliminary and final tests. Initial tests were conducted to determine the initial ability of students before PnP learning is given and the results obtained in the final test are used as a comparison to determine the success of students in following the learning using PnP. Initial test result data are presented in the following table:

Table 1

Comparative Research Class Result Data (Card Method)

\begin{tabular}{|c|c|c|c|c|c|c|}
\hline \multirow{2}{*}{ No } & \multicolumn{2}{|c|}{ Value } & \multicolumn{2}{|c|}{ Percentage } & \multirow{2}{*}{ Gain $(\%)$} & \multirow{2}{*}{ Student Group } \\
\hline & Pretes & Postes & Pretes (\%) & Postes (\%) & & \\
\hline 1 & 0,50 & 2,50 & 5 & 25 & 20 & Low \\
\hline 2 & 0,75 & 2,50 & 7,5 & 25 & 17,5 & Low \\
\hline 3 & 1,00 & 2,50 & 10 & 25 & 15 & Low \\
\hline 4 & 1,00 & 5,50 & 10 & 55 & 45 & Low \\
\hline 5 & 1,50 & 7,00 & 15 & 70 & 55 & Low \\
\hline 6 & 1,50 & 4,25 & 15 & 42,5 & 27,5 & Low \\
\hline 7 & 1,75 & 3,25 & 17,5 & 32,5 & 15 & Low \\
\hline 8 & 1,75 & 5,50 & 17,5 & 55 & 37,5 & Low \\
\hline 9 & 1,75 & 6,25 & 17,5 & 62,5 & 45 & Low \\
\hline
\end{tabular}




\begin{tabular}{|c|c|c|c|c|c|c|}
\hline \multirow{2}{*}{ No } & \multicolumn{2}{|c|}{ Value } & \multicolumn{2}{|c|}{ Percentage } & \multirow{2}{*}{ Gain $(\%)$} & \multirow{2}{*}{ Student Group } \\
\hline & Pretes & Postes & Pretes $(\%)$ & Postes (\%) & & \\
\hline 10 & 2,00 & 5,50 & 20 & 55 & 35 & Medium \\
\hline 11 & 2,00 & 5,50 & 20 & 55 & 35 & Medium \\
\hline 12 & 2,25 & 6,00 & 22,5 & 60 & 37,5 & Medium \\
\hline 13 & 2,25 & 8,25 & 22,5 & 82,5 & 60 & Medium \\
\hline 14 & 2,50 & 4,00 & 25 & 40 & 15 & Medium \\
\hline 15 & 2,50 & 2,75 & 25 & 27,5 & 2,5 & Medium \\
\hline 16 & 2,75 & 3,75 & 27,5 & 37,5 & 10 & Medium \\
\hline 17 & 2,75 & 6,50 & 27,5 & 65 & 37,5 & Medium \\
\hline 18 & 3,00 & 4,75 & 30 & 47,5 & 17,5 & Medium \\
\hline 19 & 4,50 & 1,75 & 45 & 17,5 & 27,5 & Medium \\
\hline 20 & 4,75 & 8,25 & 47,5 & 82,5 & 35 & Medium \\
\hline 21 & 5,25 & 6,25 & 52,5 & 62,5 & 10 & Medium \\
\hline 22 & 5,25 & 8,50 & 52,5 & 85 & 32,5 & Medium \\
\hline 23 & 5,50 & 5,25 & 55 & 52,5 & $-2,5$ & Medium \\
\hline 24 & 5,75 & 6,00 & 57,5 & 60 & 2,5 & Medium \\
\hline 25 & 5,75 & 6,00 & 57,5 & 60 & 2,5 & Medium \\
\hline 26 & 5,75 & 7,25 & 57,5 & 72,5 & 15 & Medium \\
\hline 27 & 6,00 & 9,50 & 60 & 95 & 35 & Medium \\
\hline 28 & 6,00 & 9,50 & 60 & 95 & 35 & Medium \\
\hline 29 & 6,25 & 5,75 & 62,5 & 57,5 & -5 & Medium \\
\hline 30 & 6,25 & 8,50 & 62,5 & 85 & 22,5 & High \\
\hline 31 & 6,25 & 7,00 & 62,5 & 70 & 7,5 & High \\
\hline 32 & 6,25 & 7,75 & 62,5 & 77,5 & 15 & High \\
\hline 33 & 6,25 & 6,75 & 62,5 & 67,5 & 5 & High \\
\hline 34 & 6,50 & 7,25 & 55 & 72,5 & 7,5 & High \\
\hline 35 & 7,00 & 8,00 & 50 & 80 & 11 & High \\
\hline \multicolumn{3}{|c|}{ Avarage } & 30 & 35 & 30 & \\
\hline
\end{tabular}

Table 2

Research Data of PnP Class

\begin{tabular}{|c|c|c|c|c|c|c|}
\hline \multirow{2}{*}{ No } & \multicolumn{2}{|c|}{ Value } & \multicolumn{2}{|c|}{ Percentage } & \multirow{2}{*}{ Gain $(\%)$} & \multirow{2}{*}{ Student Group } \\
\hline & Pretes & Postes & Pretes $(\%)$ & Postes (\%) & & \\
\hline 1 & 1,50 & 5,50 & 15 & 55 & 40 & Low \\
\hline 2 & 2,20 & 6,25 & 22 & 62,5 & 40,5 & Low \\
\hline 3 & 2,70 & 9,50 & 27 & 95 & 68 & Low \\
\hline 4 & 3,00 & 7,00 & 30 & 70 & 40 & Low \\
\hline
\end{tabular}




\begin{tabular}{|c|c|c|c|c|c|c|}
\hline \multirow{2}{*}{ No } & \multicolumn{2}{|c|}{ Value } & \multicolumn{2}{|c|}{ Percentage } & \multirow{2}{*}{ Gain (\%) } & \multirow{2}{*}{ Student Group } \\
\hline & Pretes & Postes & Pretes $(\%)$ & Postes (\%) & & \\
\hline 5 & 3,00 & 7,75 & 30 & 77,5 & 47,5 & Low \\
\hline 6 & 3,00 & 8,25 & 30 & 82,5 & 52,5 & Low \\
\hline 7 & 3,00 & 8,50 & 30 & 85 & 55 & Low \\
\hline 8 & 3,00 & 8,00 & 30 & 80 & 50 & Low \\
\hline 9 & 3,20 & 9,00 & 32 & 90 & 58 & Low \\
\hline 10 & 3,20 & 6,75 & 32 & 67,5 & 35,5 & Low \\
\hline 11 & 3,20 & 8,50 & 32 & 85 & 53 & Medium \\
\hline 12 & 3,20 & 9,75 & 32 & 97,5 & 65,5 & Medium \\
\hline 13 & 3,50 & 9,00 & 35 & 90 & 55 & Medium \\
\hline 14 & 3,50 & 8,00 & 35 & 80 & 45 & Medium \\
\hline 15 & 3,50 & 8,75 & 35 & 87,5 & 52,5 & Medium \\
\hline 16 & 3,70 & 9,75 & 37 & 97,5 & 60,5 & Medium \\
\hline 17 & 3,70 & 9,75 & 37 & 97,5 & 60,5 & Medium \\
\hline 18 & 4,00 & 9,50 & 40 & 95 & 55 & Medium \\
\hline 19 & 4,00 & 9,00 & 40 & 90 & 50 & Medium \\
\hline 20 & 4,25 & 8,50 & 42,5 & 85 & 42,5 & Medium \\
\hline 21 & 4,25 & 8,00 & 42,5 & 80 & 37,5 & Medium \\
\hline 22 & 4,50 & 9,00 & 45 & 90 & 45 & Medium \\
\hline 23 & 4,75 & 8,00 & 47,5 & 80 & 32,5 & Medium \\
\hline 24 & 4,75 & 8,00 & 47,5 & 80 & 32,5 & Medium \\
\hline 25 & 4,75 & 7,50 & 47,5 & 75 & 27,5 & Medium \\
\hline 26 & 4,75 & 9,25 & 47,5 & 92,5 & 45 & Medium \\
\hline 27 & 5,00 & 8,25 & 50 & 82,5 & 32,5 & Medium \\
\hline 28 & 5,00 & 9,00 & 50 & 90 & 40 & Medium \\
\hline 29 & 5,00 & 8,75 & 50 & 87,5 & 37,5 & Medium \\
\hline 30 & 5,50 & 9,00 & 55 & 90 & 35 & Medium \\
\hline 31 & 5,50 & 9,25 & 55 & 92,5 & 37,5 & High \\
\hline 32 & 6,00 & 9,00 & 60 & 90 & 30 & High \\
\hline 33 & 6,25 & 9,50 & 62,5 & 95 & 32,5 & High \\
\hline 34 & 6,25 & 9,25 & 62,5 & 92,5 & 30 & High \\
\hline 35 & 6,50 & 9,75 & 75 & 97,5 & 42,5 & High \\
\hline & & & 60 & 95 & 70 & \\
\hline
\end{tabular}




\section{B. Statistical Test Results}

Testing of this statistic is done to know the difference of learning outcomes between classes that are given learning using PnP with classes that are given Media learning as a class of comparison. Test results for final score as follows:

Table 3

Analysis of Learning Outcomes of Class MK and Class PnP Low Group Students

\begin{tabular}{ccc}
\hline \multirow{2}{*}{ No. } & \multicolumn{2}{c}{ \%Gain } \\
\cline { 2 - 3 } & MD Class & MP Class \\
\hline 1 & 20 & 40 \\
\hline 3 & 17 & 40,5 \\
\hline 4 & 15 & 68 \\
\hline 5 & 45 & 40 \\
\hline 6 & 55 & 47,5 \\
\hline 7 & 27 & 52,5 \\
\hline 8 & 15 & 55 \\
\hline 9 & 37 & 50 \\
\hline 10 & 20 & 58 \\
\hline Avarage & 20 & 35,5 \\
\hline
\end{tabular}

Table 4

Analysis of Learning Outcomes of MK Class and PnP Class of Medium Group Students

\begin{tabular}{ccc}
\hline \multirow{2}{*}{ No. } & \multicolumn{2}{c}{ \%Gain } \\
\cline { 2 - 3 } & MK Class & PnP Class \\
\hline 1 & 35 & 53 \\
\hline 2 & 37 & 65,5 \\
\hline 3 & 60 & 55 \\
\hline 4 & 15 & 45 \\
\hline 5 & 2,5 & 52,5 \\
\hline 6 & 10 & 60,5 \\
\hline 7 & 37,5 & 60,5 \\
\hline 8 & 17,5 & 55 \\
\hline 9 & $-27,5$ & 50 \\
\hline 10 & 35 & 42,5 \\
\hline 11 & 10 & 37,5 \\
\hline 12 & 32,5 & 45 \\
\hline
\end{tabular}




\begin{tabular}{ccc}
\hline \multirow{2}{*}{ No. } & \multicolumn{2}{c}{ \%Gain } \\
\cline { 2 - 3 } & MK Class & PnP Class \\
\hline 13 & $-2,5$ & 32,5 \\
\hline 14 & 2,5 & 32,5 \\
\hline 15 & 2,5 & 27,5 \\
\hline 16 & 15 & 45 \\
\hline 17 & 30 & 32,5 \\
\hline 18 & 35 & 40 \\
\hline 19 & -5 & 37 \\
\hline 20 & 22 & 35 \\
\hline Avarage & 20 & 45 \\
\hline
\end{tabular}

Table 5

Analysis of Learning Outcomes of MK Class and PnP Class of High Group Students

\begin{tabular}{ccc}
\hline \multirow{2}{*}{ No. } & \multicolumn{3}{c}{ \% Gain } \\
\cline { 2 - 3 } & NH Class & Hypertext Class \\
\hline 1 & 7,5 & 37,5 \\
\hline 2 & 15 & 30 \\
\hline 3 & 5 & 32,5 \\
\hline 4 & 7,5 & 30 \\
\hline 5 & 10 & 32 \\
\hline Avarage & 10 & 30 \\
\hline
\end{tabular}

Table 6

Analysis of Classroom and PnP Classroom Learning Outcomes

\begin{tabular}{ccc}
\hline \multirow{2}{*}{ No. } & \multicolumn{2}{c}{ \%Gain } \\
\cline { 2 - 3 } & MK Class & PnP Class \\
\hline 1 & 20 & 40 \\
\hline 2 & 17,5 & 40,5 \\
\hline 3 & 15 & 68 \\
\hline 4 & 45 & 40 \\
\hline 5 & 55 & 47,5 \\
\hline 6 & 27,5 & 52,5 \\
\hline 7 & 15 & 55 \\
\hline 8 & 37,5 & 50 \\
\hline 9 & 45 & 58 \\
\hline 10 & 35 & 35,5 \\
\hline
\end{tabular}




\begin{tabular}{|c|c|c|}
\hline \multirow[t]{2}{*}{ No. } & \multicolumn{2}{|c|}{ \%Gain } \\
\hline & MK Class & PnP Class \\
\hline 11 & 35 & 53 \\
\hline 12 & 37,5 & 65,5 \\
\hline 13 & 60 & 55 \\
\hline 14 & 15 & 45 \\
\hline 15 & 2,5 & 52,5 \\
\hline 16 & 10 & 60,5 \\
\hline 17 & 37,5 & 60,5 \\
\hline 18 & 17,5 & 55 \\
\hline 19 & $-27,5$ & 50 \\
\hline 20 & 35 & 42,5 \\
\hline 21 & 10 & 37,5 \\
\hline 22 & 32,5 & 45 \\
\hline 23 & $-2,5$ & 32,5 \\
\hline 24 & 2 & 32,5 \\
\hline 25 & 2 & 27,5 \\
\hline 26 & 15 & 45 \\
\hline 27 & 35 & 32,5 \\
\hline 28 & 35 & 40 \\
\hline 29 & -5 & 37,5 \\
\hline 30 & 22,5 & 35 \\
\hline 31 & 7,5 & 37,5 \\
\hline 32 & 20 & 30 \\
\hline 33 & 5 & 52,5 \\
\hline 34 & 7,5 & 30 \\
\hline 35 & 10 & 32,5 \\
\hline Ivarage & 20 & 39 \\
\hline
\end{tabular}

There is a significant difference in learning outcomes between MK classes and PnP classes. PnP learning can increase the percentage of learning outcomes from $20 \%$ to $39 \%$.

\section{Achieved Outcomes}

From the results of research activities that have been implemented in Gamaliel Christian Primary School Bandung City obtained some outcomes according to the plan that has been described in the previous chapter. The results are as follows: 
Table 6

Research Survey

\begin{tabular}{clc}
\hline No. & \multicolumn{1}{c}{ Output Type } & Indicator \\
\hline 1 & Scientific publications in journals & Accepted \\
\hline 2 & Improved understanding and skills of the community & Done \\
\hline 3 & Services, models, social engineering, systems, products / goods & Done \\
\hline
\end{tabular}

Outcomes that have been implemented as described above are activities to increase understanding and skills of society and services, models, social engineering, systems, products / goods through activities to elementary school teachers in Gamaliel Christian School. The next release is the scientific publication in the journal PGSD which will be published in September 2017 to the Journal of Primaryedu STKIP Siliwangi Bandung. In addition to the outcomes that have been delivered, there are several outpourings among them as follows:

1. The data of other research results can be used as material as data and facts for the material of final project completion (thesis) / research and can be published.

2. There is a follow-up program for the next program development year based on the evaluation of the program.

3. Increasing number of students and elementary school teachers doing PnP learning.

4. Increased understanding of learning at elementary level for students, as well as teachers.

\section{CONCLUSION}

Based on the results of the implementation of research that has been implemented in the Christian Primary School Gamaliel Bandung, it can be concluded things as follows:

1. Learning PnP can improve the ability of primary school students in knowing the sun.

2. Improved learning outcomes of students of PnP class is greater than MK class (19\%) and there are significant differences in learning outcomes among each group of students.

\section{ACKNOWLEDGMENTS}

The Chief Researcher thanked the Mandiri Research Team, Gamaliel Christian Primary School for the trust given, and RamdhanWitarsa, M.Pd. As a mentor in basic education STKIP Siliwangi Bandung. We will keep our trust and mother confidence and will continue to develop in future studies. 


\section{REFERENCES}

Abrams, R. (1997). Proceedings of "From misconceptions to constructed understanding": The Fourth International Misconceptions Seminar [On-line]. Available: http://www2ucsc.edu/ mlrg/ proc4abstracts.html. 02/03/2012.

Arnold, P., Sarge, A., \& Worrall, L. (1995). Children's knowledge of the earth's shape and its gravitational field .International Journal of Science Education, 17, 635-642.

Ausbel, D. P. (1968). Educational Psychology: A Cognitive View. New York: Holt, Rinehart and Winston, Inc.

Ball, M., \& Smith, G. (1992). Analyzing and visualizing data. London: Sage.

Banks, M. (2001).Visual methods in social research. London: Sage.

Bar, V. (1989). Children's views about the water cycle. Science Education, 73, 481-500.

Brewer, W., Hendrich, D., \&Vosniadou, S. (1987). A cross-cultural study of children's development of cosmological bodies: Samoan and American data. In Paper presented at the Third International Conference on Thinking (Honolulu, U.S.).

Caramazza, A., McCloskey, M. \& Green, B. (1981). Naïve beliefs in "sophisticated" subjects: Misconceptions about trajectories of objects. Cognition, 9, 117-123.

Clement, J. (1982).Student's preconceptions in introductory physics. American Journal of Physics, 50, 66-71.

Coates, E. (2002). 'I forgot the sky!' Children's stories contained within their drawings. International Journal of Early Years Education, 10(1), 21-35.

Collins, A. \&Gentner, D. (1987). How people construct mental models. In Cultural models in language and thought, D. Holland and N. Quinn (Eds.), Cambridge: Cambridge University Press., 243.

Cuthbert, A. J. (2000). Do children have a holistic view of their internal body maps? School Science Review, 82(299), 25-32.

Driver, R., \& Easley, J., (1978). Pupils and paradigms: a review of literature related to concept development in adolescent science students. Studies in Science Education, 5, 61-84.

Dove, J. E., Everett, L. A., \&Preece, P. F. W. (1999).Exploring a hydrological concept through children's drawings. International Journal of Science Education, 21(5), 485497.

Duit, R. \&Treagust, D. (1998).Learning in science-from behaviourism towards social constructivism and beyond. In International Handbook of Science Education, ed. B. Fraser and K. Tobin, Dordrecht, The Netherlands: Kluwer Academic, 3-26.

Edens, K. M. \& Potter, E. (2003).Using descriptive drawings as a conceptual change strategy in elementary science. School Science and Mathematics, 103, 135-144.

Gilbert, J. K., Osborne, R. J., \&Fensham, P. J. (1982).Children's science and its consequences for teaching. Science Education, 66(4), 623-633.

Golomb, C. (1992). The Child's Creation of a Pictoral World. Berkeley: University of California Press. 
Gunstone, R. F. (1990). Children's science: a decade of developments in constructivist views of science teaching and learning. The Australian Science Teachers Journal, 36(4), 1990.

Hayes, D., Symington, D., \& Martin, M. (1994).Drawing during science activity in the primary school. International Journal of Science Education, 16, 265-277.

Haslam, F. \&Treagust, D. F. (1987).Diagnosing secondary students' misconceptions of photosynthesis and respiration in plants using a two-tier multiple choice instrument. Journal of Biological Education, 21(3), 203-211.

Hewson, M. G. \& Hewson, P. W. (1983).Effect of instruction using prior knowledge and conceptual change strategies on science learning. Journal of Research in Science Teaching, 20(8), 731-743.

Henriques, L. (2002). Children's ideas about whether: A review of the literature. School Science and Mathematics, 102(5), 202-215.

Kempton, W. (1987). Two theories of home heat control. In Cultural models in language and thought, D. Holland and N. Quinn (Eds.), Cambridge: Cambridge University Press., 222.

Knoff, H. M. \&Prout, H. T. (1985). Kinetic Drawing System for family and school: A handbook. Los Angeles: Western Psychological Services.

McCloskey, M. \&Kargon, R. (1988). The meaning and use of historical models in the study of intuitive physics.In Ontogeny, phylogeny, and historical development, S. Strauss (Ed.), Norwood, NJ: Ablex, 49.

Moline, S. (1995). I see what you mean: Children at work with visual information. York, ME: Stenhouse Publishers.

Naglieri, J. A. (1988). Draw-a-Person: A quantitative scoring system. New York: Psychological Corporation.

Nobes, G., Moore, D., Martin, A., Clifford, B., Butterworth, G., Panayiotaki, G. et. al. (2003).Children's understanding of the earth in a multicultural community: Mental models or fragments of knowledge? Developmental Science, 6(1), 72-85.

Novak, J. (1987). Proceedings of the Second International Seminar: Misconceptions and Educational Strategies in Science and Mathematics. Ithaca, NY: Cornell University, Department of Education.

Nussbaum, J. (1979). Children's conceptions of the Earth as a cosmic body: A cross age study, Science Education, 63, 83-93.

Nussbaum, J. \& Novak, J. D. (1976). An assessment of children's concepts of the Earth utilizing structured interviews, Science Education, 60,535-550.

Osborne, R. J. (1983). Towards modifying children's ideas about electric current, Research in Science and Technological Education, 1, 73-82.

Osborne, R. J. \& Wittrock, M. C. (1983).Learning science: A generative process, Science Education, 67(4), 489-508.

Panagiotaki, G., Nobes, G. \& Potton, A. (2009).Mental models and other misconceptions in children's understandings of the Earth, Journal of Experimental Child Psychology, $104,52-67$. 
Posner, G. J., Strike, K. A., Hewson, P. W. \&Gertzog, W. A. (1982). Accommodation of a scientific conception: Towards a theory of conceptual change, Science Education, 66(2), 211-227.

Reith, E. (1997). Drawing development, In Child development in art, A. M. Kindler (Ed.), Virginia: National Art Education Association, 59.

Rennie, L. J. \& Jarvis, T. (1995).Children's choice of drawings to communicate their ideas about technology, Research in Science Education, 25, 239-252.

Samarapungavan, A., Vosniadou, S. \& Brewer, W. (1996). Mental models of the Earth, . A. (2004).Culture 